\title{
KEJADIAN DERAJAT LUKA DIABETES TIDAK BERHUBUNGAN DENGAN NILAI RISIKO DIABETIC FOOT ULCER
}

\author{
Risma Anggraeni Yuliastuti ${ }^{1}$, Megah Andriany ${ }^{1}$, Eka Putri Y. ${ }^{2}$ \\ ${ }^{1}$ Universitas Diponegoro \\ ${ }^{2}$ Rumah Perawatan Luka (RUMAT) Spesialis Luka Diabetes \\ E-mail: megahandriany@fk.undip.ac.id
}

\begin{abstract}
The highest diabetic complication percentage is neuropathy (54\%) causing diabetic foot ulcer (DFU). The study aimed to know the relationship between diabetic foot ulcer risk levels with diabetic ulcer severity levels. Scope of the study was diabetic wound care, particularly on legs mostly experienced by diabetic patients. The method used was descriptive correlation with cross sectional design. Sampling method was non probability with purposive sampling. Respondent number was 16 persons with inclusion criteria was diabetic patients with ulcer in one leg and no ulcer on another side in the second visitation to a diabetic clinic in Bekasi, Indonesia and agreed to be involved in the study. DFU risk level instrument modified from Diabetes Foot Screening and Risk Stratification Form of New Zealand Society for Study of Diabetes (NZSSD) to measure the DFU degree on legs with no ulcer. Another tool was to measure severity level of legs with ulcer according to Wagner. Data analysis used Kendall's tau with 0.05 of significance level. The result shows there is no relationship between DFU risk levels with severity degree of diabetic ulcers. From the study, we can conclude that nurses do not need provide specific DFU prevention based on diabetic ulcer severity grade.
\end{abstract}

Keywords: diabetic foot ulcer, diabetic mellitus, ulcer severity grade.

\section{ABSTRAK}

Prosentase komplikasi penyakit diabetes melitus tertinggi adalah neuropati (54\%) yang dapat menyebabkan terjadinya luka pada kaki pasien diabetes melitus yang biasa disebut diabetic foot ulcer (DFU). Penelitian ini bertujuan untuk mengetahui hubungan tingkat risiko diabetic foot ulcer dengan tingkat keparahan ulkus diabetikum. Ruang lingkup penelitian ini adalah pelayanan perawatan luka diabetes terutama di area kaki yang banyak dialami oleh diabetisi. Metode penelitian yang digunakan adalah deskriptif korelasional dengan desain crosssectional. Pengambilan sampel adalah non probability dengan purposive sampling. Jumlah responden yang sebanyak 16 responden dengan kriteria inklusi yaitu diabetisi dengan ulkus di salah satu kaki dan satu kaki sehat, yang datang pada kunjungan kedua ke sebuah klinik perawatan luka di Kabupaten Bekasi, dan bersedia menjadi responden. Instrumen tingkatan risiko DFU dimodifikasi dari Diabetes Foot Screening and Risk Stratification Form yang dikeluarkan oleh New Zealand Society for Study of Diabetes (NZSSD) untuk mengukur derajat DFU pada kaki tanpa ulkus dan pengukuran keparahan derajat ulkus didasarkan pada derajat ulkus menurut Wagner. Data dianalisa menggunakan Kendall's tau dengan tingkat kemaknaan 0,05. Hasil penelitian menunjukkan tidak ada hubungan antara tingkat risiko terjadinya DFU dengan tingkat keparahan ulkus diabetikum. Dengan tidak adanya hubungan tersebut dapat disimpulkan tidak diperlukan perbedaan perlakuan pencegahan DFU berdasar tingkat keparahan ulkus diabetikum.

Kata Kunci: diabetic foot ulcer, diabetes melitus, tingkat keparahan ulkus. 


\section{PENDAHULUAN}

Diabetes melitus (DM) merupakan salah satu penyakit tidak menular yang menarik perhatian masyarakat. International Diabetes Federation (IDF) menyatakan bahwa lebih dari 371 juta orang di dunia yang berumur 20-79 tahun menderita diabetes. Sedangkan Indonesia merupakan negara urutan ke-7 dengan prevalensi diabetes tertinggi dengan jumlah penderita sekitar 10 juta orang dan diperkirakan berjumlah 21,3 juta pada tahun 2030. World Health Organization (WHO) melaporkan bahwa tahun 2010 sebanyak $60 \%$ penyebab kematian semua umur di dunia dikarenakan PTM (Penyakit Tidak Menular) dan DM menduduki peringkat ke-6. Sekitar 1,3 juta orang meninggal akibat diabetes dan 4 persen meninggal sebelum usia 70 tahun. Tahun 2030 diperkirakan DM menempati urutan ke-7 penyebab kematian dunia (Kemenkes RI, 2013a; Kemenkes RI, 2013b; Hanum, 2016). Di Indonesia, DM menjadi penyebab kematian ke-6 dengan proporsi $5,7 \%$ dan penyebab kematian ke-3 dalam kategori PTM dengan proporsi 10,2\% (Depkes RI, 2008).

DM disebut silent killer karena sering tidak disadari oleh penderitanya sampai terjadinya komplikasi. Menurut data RSUP Dr. Cipto Mangunkusumo Jakarta (RSCM) pada tahun 2011, prosentase komplikasi DM tertinggi adalah neuropati sebanyak 54\% (Kemenkes RI, 2014). Neuropati perifer merupakan gangguan saraf perifer, sensoris dan motorik atau campuran yang banyak mengenai daerah distal. Pasien DM biasanya mengalami rasa $\mathrm{baal} /$ parestesia dan terkadang nyeri pada kaki berhubungan dengan hilangnya sensasi getar dan posisi (Rubeinstein, Wayne, \& Bradley, 2005). Sedangkan komplikasi yang berupa luka pada kaki pasien DM atau diabetic foot ulcer (DFU) mempengaruhi lebih kurang 15\% dari penderita DM. Ulkus diabetikum berada pada urutan ke-5 yakni 8,7\% pasien DM mengalami DFU (Kemenkes RI, 2014). DFU pada pasien DM sering berakhir dengan amputasi. Sebuah penelitian di Amerika Serikat menunjukkan bahwa 38\% dari semua kasus amputasi disebabkan oleh DM (Melinda, 2015).

Purwanti (2013b) menyatakan bahwa neuropati sensorik, neuropati otonom, dan neuropati motorik lebih sering terjadi pada kaki yang mengalami ulkus diabetikum dibandingkan dengan kaki yang tidak mengalaminya. Neuropati akan menyebabkan pasien tidak dapat merasakan rangsangan eksternal sehingga saat terluka pasien tidak mampu 
merasakan walaupun kaki telah terluka parah (Melinda, 2015).

Deteksi dini neuropati merupakan salah satu hal penting dilakukan pada pasien DM mengingat gangguan saraf dapat berupa mati rasa, akibatnya kaki tidak dapat merasakan nyeri akibatnya kaki tidak akan menyadari adanya gesekan atau tekanan pada kaki sehingga menyebabkan terjadinya DFU (Purnomo, Dwiningsih, \& Lestari, 2014). Untuk mencegah terjadinya DFU perlu dilakukan screening untuk menentukan apakah pada pasien diabetes tersebut mengalami risiko rendah ataupun tinggi mengalami DFU. Seperti penelitian yang dilakukan oleh Kusumaningrum dan Asriningati (2016) mengenai identifikasi DFU pada pasien dengan DM menyebutkan bahwa mayoritas responden memiliki risiko tinggi terhadap DFU.

Instrumen yang dapat digunakan untuk skrining dan mengetahui risiko terjadinya DFU adalah dengan menggunakan instrumen New Zealand Society for Study of Diabetes (NZSSD) yang terdiri dari 19 item yang telah dimodifikasi oleh NZSSD (Kusumaningrum \& Asriningati, 2016). Pengkajian yang dilakukan menggunakan dua unsur identifikasi yaitu subjektif dan objektif. Pengkajian subjektif dilakukan untuk mengidentifikasi pasien, riwayat pengobatan yang dijalani dan faktor risiko yang dimiliki oleh pasien. Pengkajian objektif yang dilakukan, diperlukan untuk pemeriksaan neurologi, vascular dan active foot disease. Kusumaningrum dan Asriningati melakukan pemeriksaan neurologis dengan menggunakan Ipswich Touch Test (IpTT).Pemeriksaan vaskularisasi dilakukan dengan pemeriksaan nadi dorsalis pedis dan tibiat posterior kanan maupun kiri yang meliputi frekuensi, irama nadi, maupun kualitas nadi. Sedangkan untuk pengkajian faktor risiko maupun active foot disease dilakukan dengan observasi luka/ulserasi, kelainan bentuk kaki, kalus, maupun charcot foot yang dialami klien.

Penelitian ini dilakukan dengan mengecek hubungan risiko terjadinya DFU dan tingkat keparahan ulkus diabetikum. Penelitian sebelumnya yang dilakukan oleh Kusumaningrum dan Asriningati (2016) hanya mengidentifikasi DFU pada pasien dengan diabetes melitus. Pada penelitian tersebut peneliti tidak membahas mengenai risiko DFU yang dihubungkan dengan tingkat keparahan ulkus diabetikum.

Tujuan penelitian ini adalah untuk mengetahui hubungan tingkat risiko DFU dengan tingkat keparahan ulkus diabetik. Hasil penelitian bermanfaat untuk mengetahui apakah diperlukan perbedaan perlakuan terhadap kaki sesuai dengan 
tingkat keparahan berdasarkan derajat ulkus diabetikum mengingat penelitian ini diperlukan untuk menentukan apakah diperlukan perlakuan khusus untuk meminimalisir DFU berdasarkan tingkat keparahan ulkus diabetikum pasien.

\section{METODE}

Metode penelitian yang digunakan adalah deskriptif korelasional dengan desain cross-sectional untuk mengetahui hubungan antara dua variabel dimana jenis penelitian ini menekankan waktu pengukuran/observasi data variabel independen dan dependen hanya satu kali pada satu saat (Nursalam, 2008). Penelitian ini bertujuan untuk mengetahui hubungan antara risiko DFU pada kaki sehat dengan derajat ulkus diabetikum.

Populasi dalam penelitian ini adalah semua diabetesi dengan ulkus di salah satu kakinya dan satu kaki sehat. Cara pengambilan sampel yakni dengan teknik pengambilan non probability sampling dengan menggunakan purposive sampling. Pengambilan sampel tersebut merupakan teknik penetapan sampel dengan cara memilih sampel di antara populasi sesuai dengan yang dikehendaki oleh peneliti (Nursalam, 2008). Responden penelitian yang diambil adalah diabetisi dengan ulkus di salah satu kaki dan satu kaki sehat, yang datang pada kunjungan kedua ke sebuah klinik perawatan luka di Kabupaten Bekasi, dan bersedia menjadi responden dengan menyetujui informed consent dalam rentang waktu tanggal 15-20 Desember 2016. Responden yang memenuhi kriteria tersebut sebanyak 16 orang.

Penelitian ini menggunakan instrumen skrining dan tingkatan risiko diabetic foot ulcer (DFU) yang dimodifikasi dari Diabetes Foot Screening and Risk Stratification Form oleh New Zealand Society for Study of Diabetes (NZSSD) untuk mengukur derajat DFU pada kaki sehat. NZSSD terdiri dari 4 komponen penting, yakni pemeriksaan neurologis, pemeriksaan vaskularisasi, faktor risiko dan kondisi active care. Skor maksimal penilaian adalah 16, dan dikelompokkan menjadi 3 kategori risiko DFU serta DFU aktif jika terjadi ulserasi aktif dan diduga mengalami 'charcot foot' pada kaki yang berlawanan dengan kaki dengan ulkus (NZSSD, 2014). Sedangkan untuk kaki sebaliknya (kaki dengan ulkus), pengukuran keparahan derajat ulkus didasarkan pada derajat ulkus menurut Wagner. Derajat ulkus dikategorikan menjadi 6 , yakni dari derajat 0 hingga 5 (Jain, 2012). 
Analisis data univariat dilakukan untuk mengetahui frekuensi dan prosentase karakteristik responden, penggolongan risiko DFU serta penggolongan tingkat keparahan luka ulkus diabetikum. Sedangkan analisis data bivariat dilakukan untuk mengetahui hubungan antara risiko DFU dan tingkat keparahan ulkus diabetikum. Teknik analisis bivariat pada penelitian ini menggunakan Kendall's tau untuk menguji tingkat kemaknaan statistik antara risiko DFU pada kaki sehat dengan keparahan ulkus diabetikum. Analisis bivariat Kendall's tau digunakan untuk menguji hipotesis asosiatif bila skala pengukuran datanya berbentuk ordinal dan jumlah responden lebih dari 10.

\section{HASIL DAN PEMBAHASAN}

\section{Analisis Univariat}

Analisis ini meliputi karakteristik responden, hasil pengecekan tingkat risiko DFU dan tingkat keparahan ulkus diabetikum. Responden yang mengikuti penelitian ini paling banyak responden merupakan diabetesi pada kategori lansia awal sebanyak 7 responden (43,75\%). Interval lamanya responden menderita diabetes melitus antara 2-5 tahun. Responden yang mengikuti penelitian berjumlah seimbang antara pria dan wanita, sedangkan tingkat mobilitas responden, sebagian besar responden tidak bekerja yakni sebanyak 9 responden $(57,25 \%)$.

Tabel 1

\section{Distribusi Frekuensi Tingkat Risiko Terjadinya DFU pada Pasien Diabetes} Melitus ( $n=16$ )

\begin{tabular}{cccc}
\hline No. & Tingkat Risiko DFU & $F$ & Prosentase (\%) \\
\hline 1. & Risiko Rendah & 10 & 62,5 \\
2. & Risiko Sedang & 6 & 37,5 \\
3. & Risiko Tinggi & 0 & 0 \\
4. & DFU Aktif & 0 & 0 \\
\hline & Total & 16 & 100 \\
\hline
\end{tabular}

Tabel 1 menggambarkan distribusi frekuensi tingkat risiko terjadinya DFU pada pasien DM. Mayoritas responden mengalami risiko rendah sejumlah 10 orang (62,5\%). Pada ketegori ini, sensasi proteksi utuh dan ditemukan satu atau lebih denyut nadi pada masing-masing kaki. Sebanyak 6 orang responden $(37,5 \%)$ mengalami risiko sedang dimana pada kategori ini ditemukan salah satu faktor risiko dari kehilangan sensasi proteksi, tidak 
adanya denyut nadi, deformitas kaki dengan kalus, atau lesi pre-ulkus.

Tidak ditemukan responden yang mengalami risiko tinggi maupun DFU aktif. Penderita dikategorikan risiko tinggi apabila mengalami pernah amputasi atau ulkus sebelumnya atau dengan atau lebih gejala kehilangan sensasi proteksi, tidak adanya denyut nadi, PAD, deformitas charcot, deformitas kaki dengan kalus, gagal ginjal tahap akhir, dan etnis Maori. Penderita dikategorikan DFU aktif apabila mengalami ulkus aktif di kaki, penyebaran infeksi, iskemi anggota tubuh, gangren, dan kaki bengkak dengan/atau tanpa nyeri kemungkinan charcot aktif (NZSSD, 2014).

Roza, Afriant dan Edward (2015) mengemukakan bahwa ada beberapa faktor risiko terjadinya DFU atau ulkus diabetikum, antara lain lama menderita DM, terjadinya neuropati, perawatan kaki, PAD dan trauma. Lama menderita DM sebagai salah satu faktor risiko terjadinya ulkus diabetikum tidak sejalan dengan penelitian yang dilakukan oleh Purwanti (2013a), mengungkapkan bahwa lama penderita menderita penyakit DM tidak mempengaruhi terjadinya ulkus diabetikum.
Roza, Afriant dan Edward (2015) mengungkapkan lama menderita DM bukan merupakan penyebab langsung terjadinya DFU, melainkan merupakan salah satu faktor risiko terjadinya ulkus diabetikum. Pada penelitian ini, sebagian besar responden mengalami penyakit DM selama 3 tahun yakni 9 responden. Walaupun lamanya responden menderita DM tidak berpengaruh terhadap terjadinya ulkus, tetapi semakin lama menderita DM maka kemungkinan terjadinya hiperglikemia kronik semakin besar. Salah satu efek dari hiperglikemia kronik adalah terjadinya neuropati dan DFU sebagai komplikasinya.

Neuropati merupakan salah satu risiko terjadinya ulkus diabetikum. Pernyataan ini sejalan dengan penelitian ini dimana 15 dari 16 responden yang diambil mengungkapkan bahwa dirinya mengalami nyeri neuropati yang dapat berupa nyeri, parestesia, mati rasa, sensasi terbakar ataupun rasa terbakar. Neuropati perifer merupakan gangguan saraf perifer, sensoris dan motorik atau campuran yang banyak mengenai daerah distal. Pasien DM biasanya mengalami rasa baal, parestesia dan terkadang nyeri pada kaki berhubungan 
dengan hilangnya sensasi getar dan posisi (Rubeinstein, Wayne, \& Bradley, 2005). Neuropati perifer merupakan polineuropati yang terdiri dari neuropati motorik, otonom dan sensori. Pada penelitian ini, semua responden mengalami gangguan neuropati sensorik dimana berkurangnya rasa sensitif di area kaki.

Penilaian neuropati otonom dinilai dari penilaian vaskuler, dimana nadi dorsal pedis dan tibial posterior pada kaki sehat pada 15 dari 16 responden teraba. Kondisi ini menunjukkan tidak terjadinya masalah aliran darah pada kaki sehat. Penilaian neuropati motorik dilihat dari perubahan bentuk kaki, dimana pada penelitian ini 3 dari 16 responden mengalami perubahan bentuk kaki yang menunjukkan terdapat neuropati motorik pada kaki sehat pasien.

Peripheral artery disease (PAD) juga merupakan salah satu faktor risiko terjadinya ulkus diabetikum. Pada penelitian ini, penilaian PAD didapatkan dari penilaian klaudio intermiten. Hasil penilaian menunjukkan 2 dari 16 responden mengalami klaudio intermiten pada kaki tanpa ulkus. Hal ini berarti terdapat gejala PAD pada kedua responden tersebut. PAD terjadi karena iskemia yang terjadi menyebabkan kaki merah dan kering sering bersamaan dengan neuropati, sehingga menyebabkan peningkatan risiko terjadinya ulkus diabetikum. Aliran darah yang tidak lancar di kaki menyebabkan luka sukar sembuh dan menyebabkan risiko untuk amputasi lebih besar. Proses angiopati pada penderita diabetes melitus berupa penyempitan dan penyumbatan pembuluh darah perifer, sering terjadi pada tungkai bawah terutama kaki, akibat perfusi jaringan bagian distal dari tungkai menjadi berkurang kemudian timbul ulkus diabetika (Hastuti, 2008).

Penekanan terus menerus pada telapak kaki saat berjalan juga dapat menyebabkan pasien ulkus kaki mudah sekali mengalami trauma. Faktor trauma pada pasien ulkus diabetikum bukan merupakan faktor tunggal terjadinya ulkus diabetikum, tetapi bersamaan dengan neuropati dan PAD. Trauma menyebabkan ulkus diabetikum yang sulit disembuhkan dan menjadi beban fisik dan mental bagi pasien yang menderitanya (Roza, Afriant \& Edward, 2015). 
Tabel 2

Distribusi Frekuensi Tingkat Keparahan Luka Diabetikum pada Pasien Diabetes Melitus (n=16)

\begin{tabular}{cccc}
\hline No. & Tingkat Risiko DFU & $F$ & Prosentase (\%) \\
\hline 1. & Derajat 0 & 0 & 0 \\
2. & Derajat 1 & 1 & 6,25 \\
3. & Derajat 2 & 4 & 25 \\
4. & Derajat 3 & 5 & 31,2 \\
5. & Derajat 4 & 4 & 25 \\
6. & Derajat 5 & 2 & 12,5 \\
\hline & Total & 16 & 100
\end{tabular}

Tabel 2 menunjukkan distribusi responden berdasarkan tingkat keparahan luka diabetikum. Tidak terdapat responden yang berada pada kategori derajat 0 dimana diabetisi hanya mengalami gejala di kaki seperti nyeri. Sebanyak seorang responden $(6,25 \%)$ berada pada derajat 1 yang berarti diabetisi mengalami ulkus superfisial. Empat orang responden (25\%) mengalami risiko DFU derajat 2 yang berarti menderita ulkus dalam. Responden terbanyak pada derajat 3 (ulkus dengan kerusakan tulang) yaitu sebanyak 5 orang (31,2\%). Responden lainnya sebanyak 4 orang (25\%) berada pada derajat 4 dengan gangren di kaki bagian depan dan sebanyak 2 responden $(12,5 \%)$ berada pada derajat 5 yaitu dengan gangren kaki utuh.

Berdasarkan hasil penelitian yang peneliti lakukan, responden paling banyak mengalami luka ulkus diabetikum derajat 3, dimana luka sudah sampai ke tulang. Sedangkan yang paling sedikit adalah luka ulkus dengan derajat 1 , dimana luka hanya sebatas superfisial.

Penelitian ini sejalan dengan penelitian Decroli et al. (2008) yang mengungkapkan sebanyak 55\% pasien yang datang ke RS M. Djamil Padang mengalami ulkus derajat 3, dimana infeksi telah mengenai jaringan subkutis, otot dan lebih dalam sampai ke tulang dengan tanda-tanda infeksi lokal yang jelas serta eritema dengan ukuran lebih dari $2 \mathrm{~cm}$. Penelitian ini berbeda dengan Kristiani, Sumangkut, dan Limpeleh (2015) yang memaparkan bahwa pasien yang datang ke RSUP Prof. Dr. R. D. Kandou Manado dengan luka DM sebagian besar (26,3\%) mengalami DM derajat 4. 
Rata-rata pasien yang datang ke pelayanan kesehatan sudah mengalami ulkus diabetik dengan derajat di atas 2 yang menandakan bahwa terjadi luka ulkus yang terinfeksi. Kondisi ini berkaitan dengan kualitas perawatan kaki yang dilakukan. Pada penelitian ini didapatkan hasil 11 dari 16 responden tidak melakukan perawatan kaki sehingga berpotensi untuk terjadinya ulkus diabetikum. Perawatan kaki merupakan salah satu bentuk pencegahan kaki terhadap terjadinya DFU. Kurangnya kemampuan untuk melakukan perawatan kaki secara mandiri menyebabkan pasien kurang memperhatikan luka yang terjadi dan menyebabkan infeksi.

\section{Analisis Bivariat}

Berdasarkan hasil perbandingan antara tingkat risiko terjadinya DFU dengan tingkat keparahan ulkus diabetikum disajikan dalam tabel 3.

Tabel 3

Distribusi Tingkat Risiko Terjadinya DFU dengan Tingkat Keparahan Ulkus Diabetikum pada Pasien Diabetes Melitus (n=16)

\begin{tabular}{|c|c|c|c|c|c|c|c|c|}
\hline \multirow{3}{*}{$\begin{array}{c}\text { Tingkat keparahan } \\
\text { Ulkus }\end{array}$} & \multicolumn{4}{|c|}{ Tingkat Risiko DFU } & \multirow{3}{*}{ Total } & \multirow{3}{*}{$\begin{array}{l}\text { Prosentase } \\
(\%)\end{array}$} & \multirow{3}{*}{ Nilai $r$} & \multirow{3}{*}{ Nilai $p$} \\
\hline & \multicolumn{2}{|c|}{$\begin{array}{c}\text { Risiko } \\
\text { Rendah }\end{array}$} & \multicolumn{2}{|c|}{ Risiko Sedang } & & & & \\
\hline & $F$ & $\%$ & $F$ & $\%$ & & & & \\
\hline Derajat 1 & 1 & 6,25 & 0 & 0 & 1 & 6,25 & & \\
\hline Derajat 2 & 2 & 12,5 & 2 & 12,5 & 4 & 25 & & \\
\hline Derajat 3 & 4 & 25 & 1 & 6,25 & 5 & 31,25 & 0110 & 6 \\
\hline Derajat 4 & 2 & 12,5 & 2 & 12,5 & 4 & 25 & 0,118 & 0,015 \\
\hline Derajat 5 & 1 & 6,25 & 1 & 6,25 & 2 & 12,5 & & \\
\hline Total & 10 & 62,5 & 6 & 37,5 & 16 & 100 & & \\
\hline
\end{tabular}

Tabel 3 menunjukkan bahwa jumlah responden terbanyak adalah responden dengan risiko rendah terkena DFU pada kaki sehat dan derajat 3 pada kaki dengan ulkus dengan jumlah responden 4 responden. Nilai koefisien korelasi Kendall's tau yakni 0,118 yang berarti bahwa hubungan antara kontrol glukosa darah puasa dan derajat ulkus diabetik adalah rendah atau tidak erat. Sedangkan berdasarkan pengujian signifikasi didapatkan $p=0,615$. Nilai tersebut $>0,05$ yang menunjukkan tidak ada hubungan antara tingkat risiko terjadinya DFU dengan tingkat keparahan ulkus diabetikum. 
Hasil penelitian menunjukkan bahwa bahwa tidak ada hubungan tingkat risiko terjadinya DFU pada kaki sehat dengan tingkat keparahan ulkus diabetikum. Dari hasil analisis bivariat didapatkan nilai p yakni 0,615 dan nilai r adalah 0,118. Dari hasil ini dapat disimpulkan bahwa nilai signifikasi lebih dari 0,05 yang menggambarkan bahwa tidak ada hubungan antara kedua variabel tersebut dan nilai korelasinya sangat tidak erat.

Penelitian ini sejalan dengan penelitian yang dilakukan oleh Hastuti (2008) yang menyatakan bahwa ada beberapa faktor yang terbukti sebagai faktor risiko ulkus diabetikum, antara lain lama menderita $\mathrm{DM} \geq 10$ tahun, kadar kolesterol $\geq 200 \mathrm{mg} / \mathrm{dl}$, ketidakpatuhan diit DM, kurangnya latihan fisik yaitu kebiasaan olahraga kurang dari 3 kali seminggu selama 30 menit, perawatan kaki yang tidak teratur dan penggunaan alas kaki tidak tepat dengan memberikan sumbangan secara bersama-sama terhadap ulkus diabetikum sebesar 99\%.

Sedangkan penelitian yang dilakukan oleh Purwanti (2013b), berdasarkan analisis bivariat, faktor yang berhubungan secara signifikan terhadap kejadian ulkus antara lain neuropatisensorik, neuropati otonom dan depresi. Sedangkan berdasarkan analisis multivariat, gangguan penglihatan, pengendalian kadar gula darah buruk, neuropati motorik, PAD, perawatan kaki tidak rutin berhubungan dengan kejadian ulkus kaki. Faktor yang paling dominan mempengaruhi kejadian ulkus kaki adalah neuropati motorik.

Beberapa penelitian sebelumnya menunjukkan bahwa derajat luka tidak mempengaruhi risiko kaki terhadap terjadinya ulkus diabetikum. Menurut penelitian yang dilakukan oleh Hasan (2014), faktor-faktor yang berhubungan dengan proses penyembuhan ulkus diabetikum pada RS di Provinsi Gorontalo antara lain usia penderita ulkus diabetikum, manajemen perawatan luka, nutrisi dan terdapatnya infeksi pada luka.

Penelitian ini telah diusahakan dan dilaksanakan sesuai dengan prosedur ilmiah, namun masih memiliki keterbatasan, yaitu jumlah sampel yang digunakan masih kurang dari jumlah minimum yakni 30 responden untuk uji korelasi ini berkaitan dengan jumlah responden yang datang ke klinik perawatan luka serta waktu yang minimum. Jumlah tersebut tidak 
mencapai minimum jumlah responden yakni 30 responden dikarenakan keterbatasan waktu dan jumlah kunjungan yang minim di kedua klinik perawatan luka tersebut. Namun, bila dilihat dari masing-masing kategori pada masing-masing variabel, memang tidak terdapat hubungan antara kategori-kategori tersebut. Instrumen yang digunakan juga belum memiliki penilaian baku terhadap tingkat risiko DFU sehingga dimungkinkan adanya perbedaan persepsi penilaian risiko DFU.

\section{SIMPULAN}

Penelitian ini menunjukkan bahwa sebagian besar pasien mengalami risiko rendah mengalami DFU dengan jumlah 10 responden (62,5\%), sebagian besar responden mengalami luka diabetikum derajat 3 sebanyak 5 responden $(31,2 \%)$ dan tidak ada hubungan antara tingkat risiko terjadinya DFU dengan tingkat keparahan ulkus diabetikum dengan nilai $p_{\text {value }} 0,615$ dan lebih dari nilai a 0,05 sehingga dinyatakan tidak ada hubungan antara kedua variabel tersebut. Berdasarkan hal ini, perawat dapat memberikan perlakuan yang sama pada semua kategori risiko DFU pasien.

\section{DAFTAR RUJUKAN}

Decroli, E., Karimi, J., Manaf, A., \& Syahbuddin, S. 2008. Profil Ulkus Diabetik pada Penderita Rawat Inap di Bagian Penyakit Dalam RSUP Dr. M. Djamil Padang. Majalah Kedokteran Indonesia, Volume 58, No. 1 (http://mki.idionline.org), diakses 19 November 2016.

Depkes RI. 2008. Riset Kesehatan Dasar (RISKESDAS) 2007. Jakarta.

Hanum, A. 2016. Harian Jogja.com. 31 Agustus 2016. Jumlah Penderita Diabetes Indonesia Peringkat ke-7 Dunia, (Online), (http://www.harianjogja.com/baca/201 6/08/31/jumlah-penderita-diabetesindonesia-peringkat-ke-7-di-dunia749111) diakses 7 Maret 2017.

Hasan, D. R. N. 2014. Faktor yang Berhubungan dengan Proses Penyembuhan Ulkus Diabetikum pada $R S$ di Provinsi Gorontalo. Skripsi tidak diterbitkan. Gorontalo: Program Studi Ilmu Keperawatan Fakultas Ilmu Kesehatan Dan Keolahragaan Universitas Negeri Gorontalo.

Hastuti, R. T. 2008. Faktor-Faktor Risiko Ulkus Diabetika pada Penderita Diabetes Mellitus. Tesis tidak diterbitkan. Semarang: PPS UNIVERSITAS DIPONEGORO.

Jain, A. K. C. 2012. A New Classification of Diabetic Foot Complications: A Simple and Effective Teaching Tool. Journal of Diabetic Foot Complications. (Online), Volume 5, No. 1, (http://jdfc.org/wpcontent/uploads/2012/01/v4-i1-a1.pdf), diakses 30 November 2016. 
Kemenkes RI. 2013a. Diabetes Melitus Penyebab Kematian Nomor 6 di Dunia: Kemenkes Tawarkan Solusi Cerdik Melalui Posbindu, (Online), (http://www.depkes.go.id/article/print/ 2383/diabetes-melitus-penyebabkematian-nomor-6-di-dunia-kemenkestawarkan-solusi-cerdik-melaluiposbindu.html) diakses 30 November 2016.

Kemenkes RI. 2013b. Tahun 2030 Prevalensi Diabetes Melitus di Indonesia Mencapai 21,3 Juta Orang, (Online), (http://www.depkes.go.id/article/view/ 414/tahun-2030-prevalensi-diabetesmelitus-di-indonesia-mencapai-213jutaorang.html\#sthash.GvmY1lmi.dpuf) diakses 30 November 2016.

Kemenkes RI. 2014. Situasi dan Analisis Diabetes. Jakarta: Pusat Data dan Informasi Kementrian Kesehatan RI, (Online), (http://www.depkes.go.id/download.ph p?file=download/pusdatin/infodatin/inf odatin-diabetes.pdf) diakes 30 November 2016.

Kristiani, A. L., Sumangkut, R. M., \& Limpeleh, H. P. 2015. Hubungan Ankle Brachial Index dengan Keparahan Ulkus pada Penderita Kaki Diabetik. Jurnal Biomedik. (Online), Volume 7, No. 3, (http://ejournal.unsrat.ac.id/index.php/b iomedik/article/viewFile/9488/9063), diakses 22 November 2016.

Kusumaningrum, N. S. D. \& Asriningati, R. 2016. Identifikasi Risiko Diabetic Foot Ulcer (DFU) pada Pasien dengan Diabetes Mellitus. Jurnal Luka Indonesia. II (1): 58-63.

Melinda. 2015. Gambaran Risiko Terjadinya Ulkus pada Pasien
Diabetes Melitus di Rumah Sakit Umum Daerah Dr. Moewardi. Skripsi tidak diterbitkan. Solo: Fakultas Ilmu Kesehatan Universitas Muhammadiyah Surakarta.

Nursalam. 2008. Konsep Penerapan Metodologi Penelitian Ilmu Keperawatan, Pedoman Skripsi, Tesis dan Instrumen Penelitian Keperawatan. Jakarta: Salemba Medika.

NZSSD. 2014. Diabetes Foot Screening and Risk Stratification Tool, (Online), (http://www.nzssd.org.nz/healthprofs/1 4\%2007\%20Primary\%20diabetes $\% 20 \mathrm{f}$ oot $\% 20$ screening $\% 20$ and $\% 20$ referral $\%$ 20pathways.pdf) diakses 30 November 2016.

Purnomo, S. E. C., Dwiningsih, S. U., \& Lestari, K. P 2014, 'Efektifitas Penyembuhan Luka Menggunakan $\mathrm{NaCl} 0,9 \%$ dan Hydrogel pada Ulkus Diabetes Melitus di RSU Kota Semarang', Konferensi Nasional II PPNI Jawa Tengah: prosiding konferensi, hal. 144-152.

Purwanti, O. S. 2013a. Analisis FaktorFaktor Risiko Terjadinya Ulkus Kaki pada Pasien Diabetes Mellitus di RSUD Dr. Moewardi. Tesis tidak diterbitkan. Jakarta: Fakultas Ilmu Keperawatan Universitas Indonesia.

Purwanti, O. S 2013b 'Hubungan Faktor Risiko Neuropati dengan Kejadian Ulkus Kaki pada Pasien Diabetes Mellitus Di RSUD Moewardi Surakarta. Seminar Ilmiah Nasional Kesehatan Fakultas Ilmu Kesehatan Universitas Muhammadiyah Surakarta: prosiding seminar, hal. 130-134.

Roza, R. L., Afriant, R. \& Edward, Z. 2015. Faktor Risiko Terjadinya Ulkus Diabetikum pada Pasien Diabetes Mellitus yang Dirawat Jalan dan Inap 
di RSUP Dr. M. Djamil dan RSI Ibnu

Sina Padang. Jurnal Kesehatan Andalas. IV (1): 243-248.

Rubeinstein, D., Wayne, D. \& Bradley, J. 2007. Lecture Notes: Kedokteran Klinis. Jakarta: Erlangga Medical Series. 
